\title{
Nitrogen fixation in distinct microbial niches within a chemoautotrophy-driven cave ecosystem
}

\author{
Mahesh S Desai ${ }^{1}$, Karoline Assig and Sharmishtha Dattagupta \\ Courant Research Center Geobiology, Georg-August-Universität Göttingen, Göttingen, Germany
}

\begin{abstract}
Microbial sulfur and carbon cycles in ecosystems driven by chemoautotrophy-present at deep-sea hydrothermal vents, cold seeps and sulfidic caves-have been studied to some extent, yet little is known about nitrogen fixation in these systems. Using a comprehensive approach comprising of ${ }^{15} \mathrm{~N}_{2}$ isotope labeling, acetylene reduction assay and nitrogenase gene expression analyses, we investigated nitrogen fixation in the sulfide-rich, chemoautotrophy-based Frasassi cave ecosystem (Italy). Nitrogen fixation was examined in three different microbial niches within the cave waters: (1) symbiotic bacterial community of Niphargus amphipods, (2) Beggiatoa-dominated biofilms, which occur at the sulfide-oxygen interface, and (3) sulfidic sediment. We found evidence for nitrogen fixation in all the three niches, and the nitrogenase gene (homologs of nifH) expression data clearly show niche differentiation of diazotrophic Proteobacteria within the water streams. The nifH transcript originated from the symbiotic community of Niphargus amphipods might belong to the Thiothrix ectosymbionts. Two abundantly expressed nifH genes in the Beggiatoa-dominated biofilms are closely related to those from Beggiatoa- and Desulfovibrio-related bacteria. These two diazotrophs were consistently found in Beggiatoa-dominated biofilms collected at various time points, thus illustrating species-specific associations of the diazotrophs in biofilm formation, and micron-scale niche partitioning of sulfur-oxidizing and sulfate-reducing bacteria driven by steep redox gradients within the biofilm. Finally, putative heterotrophs (Geobacter, Azoarcus and Desulfovibrio related) were the active diazotrophs in the sulfidic sediment. Our study is the first to shed light on nitrogen fixation in permanently dark caves and suggests that diazotrophy may be widespread in chemosynthetic communities.
\end{abstract}

The ISME Journal (2013) 7, 2411-2423; doi:10.1038/ismej.2013.126; published online 8 August 2013

Subject Category: Microbial ecology and functional diversity of natural habitats

Keywords: nitrogen fixation; chemoautotrophy; Beggiatoa biofilms; sulfidic sediment; Thiothrix ectosymbionts; Niphargus

\section{Introduction}

Chemoautotrophs-including bacteria that use reduced sulfur compounds, methane and hydrogen to fix inorganic carbon-occupy a variety of marine habitats, including deep-sea hydrothermal vents and cold seeps, and are the basis of the food web in these aphotic ecosystems (Stewart et al., 2005; Petersen et al., 2011). Many of these diverse bacteria are symbionts of a range of invertebrates (Dubilier et al., 2008). Chemoautotrophy is also found in non-marine habitats, such as sulfidic caves (Sarbu et al., 1996). Although microbial sulfur and carbon cycles in all such ecosystems have been studied to a certain degree, knowledge about the nitrogen cycling remains scarce.

Correspondence: MS Desai, Luxembourg Centre for Systems Biomedicine, University of Luxembourg, L-4362 Esch-sur-Alzette, Luxembourg.

E-mail: mahedesai@gmail.com

${ }^{1}$ Current address: Luxembourg Centre for Systems Biomedicine, University of Luxembourg, L-4362 Esch-sur-Alzette, Luxembourg. Received 23 December 2012; revised 2 July 2013; accepted 3 July 2013; published online 8 August 2013
Nitrogen fixation could substantially contribute to the nitrogen demand of chemoautotrophs (Rau, 1981; Brooks et al., 1987; Sarbu et al., 1996). The process involves conversion of atmospheric nitrogen gas into ammonia by the enzyme nitrogenase and is mediated by certain groups of bacteria/archaea (diazotrophs) existing in various nitrogen-deficient environments, from open oceans (Zehr et al., 2001) to termite guts (Desai and Brune, 2012). Obligate requirements for nitrogen have led several eukaryotes to establish stable symbiotic associations with phylogenetically diverse diazotrophs (Kneip et al., 2007).

Several studies have indicated that nitrogen fixation occurs in marine chemosynthetic communities: Nitrogen fixation by deep-sea anaerobic methane-oxidizing archaea was previously demonstrated (Dekas et al., 2009), and a methanogenic archaeon isolated from deep-sea hydrothermal vent fluid was found to be diazotrophic (Mehta and Baross, 2006). Using transcription and diversity analyses of the nitrogenase genes, genetic potential for nitrogen fixation was recognized in anoxic methane seeps (Miyazaki et al., 2009). Finally, 
diverse nitrogenase genes (homologs of nifH) were found in deep-sea and hydrothermal vent environments (Mehta et al., 2003) and deep-sea methane hydrate reservoirs (Dang et al., 2009; Dang et al., 2013).

We set out to study nitrogen fixation in a terrestrial chemoautotrophic environment, Frasassi caves (Italy)—a classical example of a cave formed by sulfuric acid speleogenesis (Sarbu et al., 2000; Galdenzi et al., 2008). The $23-\mathrm{km}$ cave passages formed in pure limestone harbor a microbial community dominated by sulfur-oxidizing biofilms composed of $\beta$-, $\gamma-\delta$ - and $\varepsilon$-Proteobacteria (Macalady et al., 2006). These bacteria display niche separation driven by different flow regimes as well as spatiotemporal variations of sulfide and oxygen concentrations in the water bodies (Macalady et al., 2008). Microbial biofilms formed by filamentous Beggiatoa (also containing $\delta$-Proteobacteria) and Thiothrix are common in Frasassi cave waters (Macalady et al., 2006), and some other Thiothrix spp. are ectosymbionts of Niphargus amphipods (Dattagupta et al., 2009; Bauermeister et al., 2012).

Although nitrogen fixation by cyanobacteria located at the entrance of a limestone cave has been previously shown (Griffiths et al., 1987), the process has not been demonstrated from the permanently dark areas within caves. However, the relatively depleted $\delta^{15} \mathrm{~N}$ values of the microbial mats $(-9.11$ per mil) in the chemoautotrophic Movile cave ecosystem (Romania; Sarbu et al., 1996), and the biovermiculations (sample PC06-106; - 26.5 per mil) and Beggiatoa biofilms (sample GS06-15; -9.9 per mil) found in the Frasassi caves (Jones et al., 2008) suggest diazotrophic activity. Ammonium (30-175 $\mu \mathrm{M}$ ) has been consistently measured in Frasassi cave streams (Macalady et al., 2008), despite the nitrogen demand exerted by the growth of abundant biofilms. The source of the bioavailable nitrogen within Frasassi is yet unknown. The caves receive almost no aboveground organic input (Galdenzi et al., 2008), but some ammonium could presumably be from the mineralized aquifer originating from deeply buried anhydrite rocks underlying the Frasassi cave network (Sarbu et al., 2000). Alternatively, the bioavailable nitrogen might be produced by diazotrophs autochthonously.

We investigated whether nitrogen fixation occurs in the Frasassi caves using a multifaceted approach consisting of acetylene reduction assays that utilize the ability of the nitrogenase enzyme to reduce acetylene to ethylene (Stewart et al., 1967), analyses of the incorporation of heavy nitrogen isotope $\left({ }^{15} \mathrm{~N}_{2}\right.$; Montoya et al., 1996) and expression and phylogenetic analyses of the nifH genes (Zehr et al., 2003b). As nitrogen fixation can be carried out by some Thiothrix spp. (Chernousova et al., 2009) and Beggiatoa spp. (Nelson et al., 1982) and is present in several types of sediments (Herbert, 1999; Dekas et al., 2009; Hamilton et al., 2011), we selected to examine the following niches in the cave waters: (1) symbiotic bacterial communities of Niphargus amphipods, including host-specific Thiothrix ectosymbionts attached to their legs (Bauermeister et al., 2012); (2) Beggiatoa-dominated biofilms (Macalady et al., 2008), which generally occur at the interface between oxygen and sulfide availability (Jørgensen, 1977; Nelson et al., 1986); and (3) sulfidic sediment.

\section{Materials and methods}

Sample collection and geochemical measurements Table 1 shows all the samples utilized in this study and the corresponding sampling times. Cave water parameters, namely $\mathrm{pH}$, conductivity, sulfide and oxygen concentrations, were measured in the overlying water while collecting most of the samples at the Grotta Grande del Vento-Grotta del Fiume (Frasassi), Italy $\left(43.4306^{\circ} \mathrm{N}, 12.9358^{\circ}\right.$ E); for site map, see Bauermeister et al. (2012). Samples were collected within $15 \mathrm{~min}$ after the geochemical analyses were made. Sulfide was measured using the Methylene Blue method (HACH LANGE, GmbH, Germany), and oxygen, $\mathrm{pH}$ and conductivity were measured using electrodes LDO101, PHC101 and CDC401, respectively, connected to an HQ40d multimeter (all acquired from HACH LANGE, GmbH, Germany). Ammonia measurements were made with water samples taken from the above Beggiatoa-dominated biofilms, which were collected shortly thereafter (for details of sampling of Beggiatoa biofilm, see below). To determine ammonium concentrations, water samples were filled into falcon tubes without any air bubble and transported to the nearby field station, Osservatorio Geologico di Coldigioco. Ammonium concentrations were measured within $6 \mathrm{~h}$ after collection using the AmVer high range ammonium measurement kit (HACH LANGE, $\mathrm{GmbH}$, Germany), according to the manufacturer's instructions.

Specimens of Niphargus ictus, Niphargus frasassianus and Niphargus montanarius were collected at various locations (see Table 1 for names of the locations); for identification and sampling details, see Flot et al. (2010) and Bauermeister et al. (2012). Samples were rapidly preserved in RNAlater (Ambion/Applied Biosystems, Foster City, CA, USA), transported to Osservatorio Geologico di Coldigioco on cool packs ( $\sim$ subzero temperatures) and stored at $-20{ }^{\circ} \mathrm{C}$ within $4 \mathrm{~h}$ after collection.

The Beggiatoa-dominated biofilms (referred to as Beggiatoa biofilms hereafter) were identified based on their conspicuous cottony morphology and growth on the silty sediment in slowly flowing waters (Table 1; Macalady et al., 2006). Beggiatoa biofilms were usually present as a continuous patch spread over $\sim 4-10 \mathrm{~m}^{2}$. The biofilm was collected over a length of several meters and pooled 
Table 1 Sampling details of Niphargus spp. (Niphargus ictus, Niphargus frasassianus and Niphargus montanarius), Beggiatoa and $\varepsilon$-Proteobacteria biofilms and sediment in the Frasassi caves

Sample $\begin{aligned} & \text { Sampling Experiments } \\ & \text { time }\end{aligned}$

Niphargus spp.
N. frasassian

N. frasassianus (ST)

N. ictus (PC)

June 2009 RNA extraction from

July 2010 the whole animals, reverse transcriptase (RT)-PCR amplification of nifH

homologs

$N$. frasassianus $(\mathrm{ST})^{\mathrm{a}}$

May 2009

N. frasassianus (RS)

May 2009

nifH amplification

N. montanarius A (BG) ${ }^{\mathrm{a}}$

January

2008

N. montanarius B (BG) ${ }^{\mathrm{a}} \quad$ January

2008

from DNA extracted

from the symbiotic

microbial community

associated with

separated legs

Beggiatoa-dominated biofilms PC-BeggA

July 2010

Total RNA extraction, and RT-PCR amplification of 16S rRNA and nifH

PC-BeggB

PC-BeggC

February Acetylene reduction 2011 assay

May 2011 Acetylene reduction assay, Isotope Ratio Mass Spectrometry (IRMS) and RT-PCR amplification of nifH homologs

ع-Proteobacteria biofilm PC-Epsila

July 2010 IRMS

Sulfidic sediment

PC-SedA

PC-SedB

February

2011

March

2011

PC-SedC

May 2011

PC-SedD

July 2011
Acetylene reduction assay

${ }^{15} \mathrm{~N}_{2}$ isotope labeling and IRMS

Acetylene reduction assay and IRMS

Total RNA extraction and RT-PCR amplification of nifH

homologs

Abbreviations: BG, Il Bugianardo; PC, Pozzo dei Cristalli; RS, Ramo Aubreviations: BG, Il Bugianardo; 1 ,

The experiments performed with the samples are mentioned in brief (for details, refer to Materials and methods). Collection locations within the Frasassi cave complex are provided in parentheses (see Bauermeister et al., 2012, for a cave map). In March and July 2011, no Beggiatoa biofilms were present at PC; moreover, water levels were elevated in the cave by $\sim 1 \mathrm{~m}$ as compared with the levels observed during other collections.

${ }^{a}$ These samples were collected as a part of other studies and the same DNA preparations were used here (Flot et al., 2010; Bauermeister et al., 2012).

together, which was finally treated as one sample. The pooling was necessary to obtain enough material for our analyses. The samples were collected in $50 \mathrm{ml}$ falcon tubes with sterile Pasteur pipettes; utmost care was taken to avoid mixing of the underlying sediment. The samples were overlaid with 10-15 ml of cave water and an air headspace of $10-15 \mathrm{ml}$ and transported and stored at the in situ

temperature $\left(13^{\circ} \mathrm{C}\right)$ in the dark. It was impossible to collect the Beggiatoa biofilms without collecting minor amounts of sediment particles. However, the Beggiatoa biofilms completely rearranged inside the falcon tubes within $\sim 8 \mathrm{~h}$ after collection. The almost pure biofilm was then carefully pipetted from several falcon tubes, pooled together, immediately preserved in RNAlater and processed similar to the Niphargus samples (see above). The remaining portion was transported to Germany for the nitrogenase activity assay (see below). The biofilm remained alive (as seen by aggregation behavior) in the falcon tubes for 2-3 weeks. The $\varepsilon$-Proteobacteria biofilm was identified based on morphology and niche characteristics described by Macalady et al. (2008) and preserved in RNAlater.

Sediment samples were collected $0-15 \mathrm{~cm}$ under the sediment-water interface. Samples were collected over a length of $5 \mathrm{~m}$ along the water stream and were subsequently pooled to get a homogenous representative sample. The samples for nitrogenase activity assays and ${ }^{15} \mathrm{~N}_{2}$ isotope analysis were overlaid with cave water and transported and stored at the in situ cave temperature $\left(13^{\circ} \mathrm{C}\right)$ in the dark. The sample collected for RNA extraction was immediately preserved in LifeGuard Soil Preservation Solution, following the manufacturer's instructions (MO BIO Laboratories, Carlsbad, CA, USA), and transported and stored similar to the Niphargus samples. The killed controls for the nitrogenase assays were prepared by adding $\mathrm{HgCl}_{2}$ (1 mM final concentration) within $6 \mathrm{~h}$ of collection to sediment and Beggiatoa biofilm samples (Hamilton et al., 2011).

${ }^{15} \mathrm{~N}_{2}$ uptake analyses

The isotope labelling experiments with ${ }^{15} \mathrm{~N}_{2}$ (98 atom \% ${ }^{15} \mathrm{~N}_{2}$ gas, Sigma Aldrich, Munich, Germany) were performed with the sediment samples within $10 \mathrm{~h}$ of collection (Table 1). As it was necessary to exclude ammonium from the labelling medium, we did not use the Frasassi cave water in our labelling experiments. Instead, we prepared a basic salt solution (BSS), including all the major ions found in the cave waters, that is, $\mathrm{CaSO}_{4}(2 \mathrm{~mm})$, $\mathrm{KCl}$ (0.8 mM), $\mathrm{MgCl}_{2} \cdot 6 \mathrm{H}_{2} \mathrm{O}$ (0.8 mM), $\quad \mathrm{MgSO}_{4} \cdot \mathrm{H}_{2} \mathrm{O}$ (0.1 mM) and $\mathrm{NaCl}$ (17.6 mM), with $\mathrm{pH} 7.2$ and conductivity $3.27 \mathrm{mS} \mathrm{cm}^{-1}$.

As the ${ }^{15} \mathrm{~N}_{2}$ bubble method can underestimate the rates of nitrogen fixation, we used the ${ }^{15} \mathrm{~N}_{2}$ saturation method (Mohr et al., 2010; Großkopf et al., 2012). For ${ }^{15} \mathrm{~N}_{2}$ labelling, 1 liter serum bottles were completely filled with BSS without any air bubble, and the bottles were closed with butyl rubber septa. In order to avoid mixing of atmospheric gas with the ${ }^{15} \mathrm{~N}_{2}$ gas, the headspace of the ${ }^{15} \mathrm{~N}_{2}$ gas cylinder pressure gauge was flushed 3-4 times with helium using a gas-tight syringe. The same syringe was immediately used to inject $6.0 \mathrm{ml}$ of ${ }^{15} \mathrm{~N}_{2}$ gas at the atmospheric pressure into the bottle with BSS. The 
BSS with the ${ }^{15} \mathrm{~N}_{2}$ gas bubble was stirred overnight $(>18 \mathrm{~h})$ at room temperature. The final calculated ${ }^{15} \mathrm{~N}_{2}$ label in the medium was $\sim 36.8$ atom $\%$. The bottles were stored at $13{ }^{\circ} \mathrm{C}$ until further analysis.

Thick slurries of the sediment samples (50:50 sediment-to-water ratio) were prepared with the cave water collected at the same time when the sediment samples were collected. Ten milliliters of slurry was taken in 50-ml serum bottles and was allowed to settle in the bottle. In the mean time, the 1-liter serum bottles containing the BSS- ${ }^{15} \mathrm{~N}_{2}$ label were opened. This was immediately followed by the addition of $\mathrm{NaHCO}_{3}$ into the $\mathrm{BSS}-{ }^{15} \mathrm{~N}_{2}$ at a final concentration of $0.4 \mathrm{mg} \mathrm{ml}^{-1}$ and sulfide $\left(\mathrm{Na}_{2} \mathrm{~S}\right)$ at a concentration of $125-150 \mu \mathrm{M}$. A range of sulfide concentrations is provided as some sulfide got oxidized, and therefore, it was not possible to get a stable value. Later, the $\mathrm{pH}$ of the labelling medium was adjusted to 7.2. To reduce mixing of atmospheric nitrogen with the ${ }^{15} \mathrm{~N}_{2}$-saturated medium, all the additions after opening the BSS- ${ }^{15} \mathrm{~N}_{2}$ bottle were performed as quickly as possible. The 'no ${ }^{15} \mathrm{~N}_{2}$ isotope' label control was prepared similarly except that $6.0 \mathrm{ml}$ air was injected into the bottle instead of the ${ }^{15} \mathrm{~N}_{2}$ gas. The labelling medium was gently transferred to all the serum bottles, including the control bottles. The bottles were carefully closed with butyl septa without introducing any air bubbles. Neglecting the minor loss of the ${ }^{15} \mathrm{~N}_{2}$ label while handling, the final calculated label in the incubation bottle would be $\sim 31$ atom \%. The incubations were carried out at the in situ temperature $\left(13^{\circ} \mathrm{C}\right)$ in dark. Incubations were performed for a total of seven time points: $0,6,12,24,36,48$ and $120 \mathrm{~h}$ (each in duplicate). The bottles were opened, and the contents were processed after each time point (the bottles were discarded); for the $0 \mathrm{~h}$ time point, the bottles were closed and opened immediately. The supernatant was partially removed without disturbing the sediment slurry, and the settled sediment samples $(1 \mathrm{ml}$ each) were transferred to 2$\mathrm{ml}$ glass vials and immediately frozen at $-20^{\circ} \mathrm{C}$. In addition to the no- ${ }^{15} \mathrm{~N}_{2}$ control, a $\mathrm{Na}_{2} \mathrm{MoO}_{4}$ (molybdate)-amended control (final concentration $20 \mathrm{~mm}$ ) was carried out to inhibit sulfate reduction by molybdate (Oremland and Capone, 1988) and thereby check whether sulfate reducers are dominant diazotrophs in this system.

\section{Isotope Ratio Mass Spectrometry (IRMS)}

All the frozen sediment samples from the ${ }^{15} \mathrm{~N}_{2}$ uptake experiment and the samples preserved in RNAlater (including the $\varepsilon$-Proteobacteria biofilm) were subjected to IRMS analyses (see Table 1 for sample names). The samples were freeze-dried overnight using a Christ Alpha I-5 dryer (Martin Christ Gefriertrocknungsanlagen $\mathrm{GmbH}$, Osterode am Harz, Germany). The freeze-dried materials were homogenized manually with a small metal rod to fine powders. The powdered materials were weighed in tin capsules (4-10 mg each), packed and subjected to IRMS at the Centre for Stable Isotope Research and Analysis, Göttingen, Germany (Werner et al., 1999).

\section{Acetylene reduction assay}

Nitrogenase activity in Beggiatoa and sediment samples was determined within 7 days of collection. The almost-pure Beggiatoa biofilms isolated in the second round and the sediment slurry (both prepared as mentioned above) were subjected to the acetylene reduction assay. The sediment slurry was prepared a day before the experiments; $10 \mathrm{ml}$ slurry was distributed in $50-\mathrm{ml}$ serum bottles and was allowed to settle overnight; the control with molybdate (final concentration $20 \mathrm{~mm}$ ) was also prepared at the same time. The second round of biofilm purification was performed an hour before injecting acetylene, and $1 \mathrm{ml}$ biofilm was taken into $10-\mathrm{ml}$ serum bottles, except that the control with molybdate was prepared a day earlier. It should be noted that the biofilms actively aggregated in the serum bottles, confirming that they were alive. The samples, including the $\mathrm{HgCl}_{2}$-killed controls and filter-sterilized cave water, were sealed with rubber stoppers, and $15 \%$ pure acetylene at atmospheric pressure was injected with a gas-tight syringe. The incubations were carried out at $13^{\circ} \mathrm{C}$ in dark for $16 \mathrm{~h}$. The headspace (100-250 $\mu \mathrm{l})$ samples were examined for ethylene by gas chromatography (GC 14b; Shimadzu, Griesheim, Germany). The gas chromatograph comprised of a flame ionization detector and a stainless-steel column filled with Porapak R (Macherey-Nagel, Darmstadt, Germany, $80 / 100$ mesh, $\left.6^{\prime} \times 1 / 8^{\prime \prime}\right)$. Nitrogen was used as a carrier gas (isothermal conditions, $40^{\circ} \mathrm{C}$ ). Later, the samples were dried at $80^{\circ} \mathrm{C}$ for $48 \mathrm{~h}$ and weighed.

\section{Nucleic acid extraction}

DNA extraction procedure from the legs of Niphargus spp. is mentioned previously (Bauermeister et al., 2012). Total RNA extraction from the RNAlater-preserved Niphargus and Beggiatoa biofilm samples were performed using TRIzol Reagent (Invitrogen, Karlsruhe, Germany) with the following modifications: Niphargus individuals (3-5) and Beggiatoa biofilm (1 ml) were centrifuged (6000 g, $5 \mathrm{~min}, 4^{\circ} \mathrm{C}$ ). Excessive RNAlater was removed and to remove the loosely attached bacteria, the samples were washed three times with phosphate-buffered saline $(0.13 \mathrm{M} \mathrm{NaCl}, 10 \mathrm{~mm}$ Na-phosphate; pH 7.4). Bead beating was performed at 5700 r.p.m. for two cycles of $45 \mathrm{~s}$, with a pause of $20 \mathrm{~s}$. As these RNAlater-preserved samples had high amounts of salt, we determined that treating the samples two times with TRIzol, with half the TRIzol amount for the second time, led to optimal RNA purity and yield (NanoDrop measurements: 260/280 and 260/230 ratios close to 2.0 ). Therefore, after the 
first TRIzol addition $(1 \mathrm{ml})$, bead beating and centrifugation, the upper phase was removed and half the volume of TRIzol (that is, $0.5 \mathrm{ml}$ ) was added to the upper phase. The samples were then vigorously mixed and were treated according to the manufacturer's instructions (Invitrogen). The RNA samples were dissolved in nuclease-free water and stored at $-20^{\circ} \mathrm{C}$.

RNA was extracted from sediment samples using the RNA PowerSoil Total RNA Isolation Kit (MO BIO Laboratories), following the manufacturer's instructions. RNA samples were resuspended in RNase/DNase-free water (Solution SR7) provided with the MO BIO RNA PowerSoil Kit; the RNA samples were stored at $-20^{\circ} \mathrm{C}$. RNA extractions with RNAlater-preserved sediment samples were never successful (details not shown). This might be owing to the high salt concentration in the samples and RNAlater. However, when we preserved the samples in LifeGuard Soil Preservation Solution (MO BIO Laboratories), good quality RNA extracts were obtained (NanoDrop measurements: 260/280 and $260 / 230$ were nearly 2.0 ). Integrity of all the RNA samples (that is, Niphargus spp., Beggiatoa biofilms and sediment) was confirmed by standard agarose gel (2\%) electrophoresis.

\section{PCR, reverse transcriptase (RT)-PCR and cloning of nifH homologs}

We tested multiple sets of previously published nifH primer sets on the DNA extracted from the microbial community associated with the legs of Niphargus, Beggiatoa biofilms and the sediment samples (details not shown; Ohkuma et al., 1999; Zehr et al., 2003a; Hongoh et al., 2008; Hamilton et al., 2011). Among all the primer sets, the nested-PCR approach of Zehr et al. (2003a) (outer primers, nifH3 and nifH4; inner primers, nifH1 and nifH2) provided optimum results, with sharp bands of expected size ( $\sim 360 \mathrm{bp}$ ) and no non-specific amplification. Thirty-five cycles were used for the both primer sets, and the optimum $\mathrm{MgCl}_{2}$ concentration was $2.5 \mathrm{~mm}$. Addition of bovine serum albumin $\left(1 \mu \mathrm{l}\right.$ of $0.4 \mathrm{mg} \mathrm{ml}^{-1}$ in $50 \mu \mathrm{l}$ PCR mixture) enhanced the PCR product quality and was therefore routinely added in all the reactions.

The primer sets of Zehr et al. (2003a) were used to amplify the nifH genes from the ectosymbiotic microbial community associated with the legs of Niphargus and nifH transcripts from the RNA extracted from the symbiotic community associated with the whole Niphargus animals, the Beggiatoa biofilms and the sediment (Table 1). Single-tube, one-step, two-enzyme RT-PCR (Access RT-PCR System kit, Promega, Mannheim, Germany) was performed with RNA extracts digested with RNase-free DNase (RQ1, Promega), according to the manufacturer's instructions. One microliter of the cDNA template obtained from the RT-PCR was used for the nested PCR. Quality of the PCR products was checked by standard agarose gel (1\%) electrophoresis. Simultaneous assays without reverse transcriptase did not produce any products, confirming the absence of DNA template in the RNA extracts. Moreover, the DNase-digested RNA extracts were subjected to amplification of the $16 \mathrm{~S}$ rRNA genes, and no PCR products were obtained, corroborating the absence of DNA templates. Assays without RNA templates did not produce any products, confirming purity of the RT-PCR and PCR chemicals.

All the amplicons were cloned using TOPO TA cloning kit, following the manufacturer's instructions (Invitrogen). Inserts were sequenced using T3 and T7 primers at the Göttingen Genomics Laboratory (Göttingen, Germany). The nifH gene sequences have been submitted to the EMBL/GenBank database under accession numbers HF565511-HF565570 (Table 2).

\section{Phylogenetic analysis}

For phylogenetic analysis of nifH homologs, we constructed a complete database of cultured representatives of all the standard nifH lineages (Zehr et al., 2003b), using the ARB software suite (http://www.arb-home.de). The translated amino-acid sequences derived from the sequences obtained in this study were subjected to BLASTp, and the closest nifH sequences (originating from both cultured and uncultured bacteria) were imported in the database. Phylogenetic tree was calculated from the translated amino-acid sequences using the maximum-likelihood algorithm provided in ARB (PhyML with Dayhoff PAM, 100 bootstraps); tree topology was validated with maximum-parsimony analysis (PHYLIP Protein parsimony; 1000 bootstraps).

\section{Results}

\section{Geochemical parameters}

Samples corresponding to the geochemical parameters reported here are mentioned in Table 1. Conductivity and $\mathrm{pH}$ values were in the same range as reported earlier (Macalady et al., 2006). All the values of sulfide and ammonium reported here are the averages of three measurements. Sulfide concentrations in the location Pozzo dei Cristalli (PC) where most of the samples were collected were $419 \mu \mathrm{M}$ (June 2009), $459 \mu \mathrm{M}$ (July 2010), $267 \mu \mathrm{M}$ (March 2011) and $356 \mu \mathrm{M}$ (May 2011). Oxygen values in PC varied between $12 \mu \mathrm{M}$ (June 2009), $30 \mu \mathrm{M}$ (July 2010), $28 \mu \mathrm{M}$ (March 2011) and $26 \mu \mathrm{M}$ (May 2011). Sulfide was always non-detectable and oxygen $\sim 150 \mu \mathrm{M}$ in six sampling trips (2007-2011) to the location BG where $N$. montanarius was collected. In locations where $N$. frasassianus individuals were collected in May-June 2009, sulfide was $136 \mu \mathrm{M}$ (ST) and $109 \mu \mathrm{M}$ (RS), and oxygen was $31 \mu \mathrm{M}$ (ST) and $10 \mu \mathrm{M}$ (RS). Sulfide and oxygen values for samples collected in May-June 2009 were previously reported in Flot et al. (2010) and were not determined for samples 
Table 2 Phylotypes of nifH homologs obtained from different samples (Niphargus frasassianus, Niphargus montanarius, Beggiatoa-dominated biofilms and sulfidic sediment) collected at different sites in the Frasassi cave complex

\begin{tabular}{|c|c|c|c|c|}
\hline Sample & Phylotypes & Phylogenetic group & $\begin{array}{l}\text { cDNA } \\
\text { or DNA } \\
\text { clones/ } \\
\text { library }\end{array}$ & Genotypes $^{\mathrm{a}}$ \\
\hline \multicolumn{5}{|l|}{ Niphargus spp. } \\
\hline \multirow[t]{2}{*}{ N. frasassianus (ST) total RNA } & Thio1a & $\gamma$-Proteobacteria (I) & $14 / 15$ & HF565531-38 \\
\hline & Thio1b & $\gamma$-Proteobacteria (I) & $1 / 15$ & HF565539 \\
\hline \multirow{3}{*}{ N. frasassianus (ST) legs DNA } & Thio1a & $\gamma$-Proteobacteria (I) & $2 / 8$ & HF565540 \\
\hline & Thio1d & $\gamma$-Proteobacteria (I) & $3 / 8$ & HF565541-43 \\
\hline & Thio1e & $\gamma$-Proteobacteria (I) & $3 / 8$ & HF565544-46 \\
\hline \multirow{5}{*}{ N. frasassianus (RS) legs DNA } & Thio1a & $\gamma$-Proteobacteria (I) & $3 / 8$ & HF565555-57 \\
\hline & Thio1c & $\gamma$-Proteobacteria (I) & $1 / 8$ & HF565558 \\
\hline & Thio1d & $\gamma$-Proteobacteria (I) & $1 / 8$ & HF565560 \\
\hline & Thio1e & $\gamma$-Proteobacteria (I) & $2 / 8$ & HF565559, HF565561 \\
\hline & Geob & Geobacter (I) & $1 / 8$ & HF565569 \\
\hline \multirow{3}{*}{ N. montanarius A (BG) legs DNA } & Thio1a & $\gamma$-Proteobacteria (I) & $6 / 9$ & HF565547-51 \\
\hline & Thio1c & $\gamma$-Proteobacteria (I) & $2 / 9$ & HF565552-53 \\
\hline & Thio1d & $\gamma$-Proteobacteria (I) & $1 / 9$ & HF565554 \\
\hline \multirow[t]{3}{*}{ N. montanarius B (BG) legs DNA } & Thio1a & $\gamma$-Proteobacteria (I) & $3 / 7$ & HF565562 \\
\hline & Thio1c & $\gamma$-Proteobacteria (I) & $3 / 7$ & HF565563-65 \\
\hline & Thio1d & $\gamma$-Proteobacteria (I) & $1 / 7$ & HF565566 \\
\hline \multicolumn{5}{|l|}{ Beggiatoa-dominated biofilm } \\
\hline \multirow[t]{5}{*}{ PC-BeggA total RNA } & Desulfo1a & Desulfovibrio (III) & $15 / 22$ & HF565524-27 \\
\hline & Desulfo1b & Desulfovibrio (III) & $1 / 22$ & HF565511 \\
\hline & Desulfo1d & Desulfovibrio (III) & $1 / 22$ & HF565529 \\
\hline & Begg & Beggiatoa (I) & $3 / 22$ & HF565530 \\
\hline & Geob & Geobacter (I) & $2 / 22$ & HF565569 \\
\hline \multirow{4}{*}{ PC-BeggC total RNA } & Desulfo1a & Desulfovibrio (III) & $22 / 28$ & HF565513-23 \\
\hline & Desulfo1c & Desulfovibrio (III) & $1 / 28$ & HF565528 \\
\hline & Desulfo2 & Desulfovibrio (III) & $1 / 28$ & HF565512 \\
\hline & Begg & Beggiatoa (I) & $4 / 28$ & HF565530 \\
\hline \multicolumn{5}{|l|}{ Sulfidic sediment } \\
\hline \multirow[t]{4}{*}{ PC-SedD total RNA } & Thio2 & $\gamma$-Proteobacteria (I) & $10 / 30$ & HF565567 \\
\hline & Azoarc & Azoarcus (I) & $4 / 30$ & HF565568 \\
\hline & Geob & Geobacter (I) & $12 / 30$ & HF565569 \\
\hline & Desulfo3 & Desulfovibrio (III) & $4 / 30$ & HF565570 \\
\hline
\end{tabular}

The abundance of each phylotype (derived from cDNA or DNA) and the GenBank accession numbers of the corresponding genotypes are provided. Abbreviations of collection locations within the Frasassi caves are provided in parentheses; see Table 1 for full names. For phylogenetic positions of individual phylotypes, see Figure 2. In parentheses are the phylogenetic assignments (I or III) to the existing nifH groups (Zehr et al., 2003b).

${ }^{a}$ For sequences showing the same amino-acid signature, representative sequences were submitted to GenBank. When nearly identical genotypes were obtained from two different samples, representatives from both libraries were submitted—such genotypes usually had >99\% DNA sequence similarity.

collected in January 2008, February 2011 and July 2011. Ammonium concentrations in PC were $142 \mu \mathrm{M}$ (July 2010) and $105 \mu \mathrm{M}$ (May 2011); note that the ammonium measurement method used in this study only provides approximate concentrations.

\section{Nitrogenase activity assay}

Both samples each of Beggiatoa biofilms and sulfidic sediment investigated in this study showed formation of ethylene in the acetylene reduction assay, demonstrating nitrogenase activity in these samples (Table 3). In the Beggiatoa biofilms, the rates of ethylene production were nearly twofold higher for the biofilm collected in May as compared with the biofilm collected in February (Tables 1 and 3 ). However, the ethylene production rates for the sediment samples collected in February and May did not show considerable difference (Table 3). The molybdate-amended Beggiatoa biofilms (PC-BeggC) showed an order of magnitude decrease in the ethylene production. It should be noted that the molybdate-amended biofilms did not show aggregation behavior and their color had changed from white to light red. On the contrary, ethylene production by the molybdate-amended sediment samples (PC-SedC) showed no difference. Even after $16 \mathrm{~h}$ of incubation with acetylene, no ethylene production was detected in $\mathrm{HgCl}_{2}$-killed (carried out only for samples collected in May 2011) and filter-sterilized cave water controls, as well as for unfiltered cave water controls (data not shown), confirming that the nitrogenase activity originated from the biofilm and sediment samples. Although we 
also performed the acetylene reduction assay with live amphipods (10-15 individuals of $N$. frasassianus) collected from the cave site PC, no ethylene was detected (details not shown); the ethylene signal might be below the detection limit of the gas chromatograph (3.5 pmol), owing to an insufficient number of animals used for the assay.

$\delta^{15} \mathrm{~N}$ natural abundance and ${ }^{15} \mathrm{~N}_{2}$ uptake analyses Stable isotope ratios of carbon $\left(\delta^{13} \mathrm{C}\right)$ and nitrogen $\left(\delta^{15} \mathrm{~N}\right)$ for several samples were as follows (shown as $\delta^{13} \mathrm{C}$ and $\delta^{15} \mathrm{~N}$ in per mil, respectively): Beggiatoa-dominated biofilm (PCBeggC; $n=4$ ), $-35.347 \pm 2.254$ and $-12.984 \pm 0.194 ; \quad \varepsilon$-Proteobacteria biofilm (PC-EpsilA; $n=4),-29.894 \pm 0.230$ and $-1.041 \pm 0.240$; and sulfidic sediment (PC-SedB; $n=4),-23.709 \pm 0.624$ and $-1.389 \pm 0.285$. All four replicates for each sample were derived from the same starting sample; see Table 1 for sample names. Similar results were found for the sediment sample collected in May 2011 (PC-SedC; data not shown). The $\delta^{15} \mathrm{~N}$ of the Beggiatoa biofilm (PCBeggC) was substantially depleted in comparison with the $\varepsilon$-Proteobacteria biofilm and sediment. The ${ }^{15} \mathrm{~N}_{2}$ labelling experiment with one sediment sample (PC-SedB) showed a clear increase in $\delta^{15} \mathrm{~N}$, except for the last time point $(120 \mathrm{~h})$ where the uptake seemed to stabilize (Figure 1). A control without ${ }^{15} \mathrm{~N}_{2}$ isotope label did not exhibit any incorporation, corroborating that the sediment actively fixes nitrogen. The molybdate-supplemented sediment showed no significant change in the uptake of ${ }^{15} \mathrm{~N}_{2}$ isotope label, thus providing similar results to the nitrogenase activity assays (see above).

Based on the amount of ${ }^{15} \mathrm{~N}_{2}$ label incorporated in the sediment (PC-SedB), rates of nitrogen fixation were calculated (Capone and Montoya, 2001)—the rates (expressed in nmol $\mathrm{N}_{2}$ fixed $\mathrm{g}^{-1} \mathrm{~h}^{-1}$ ) for the individual time points in the ${ }^{15} \mathrm{~N}_{2}$ uptake experiment were $0.266 \pm 0.112(6 \mathrm{~h}), 0.387 \pm 0.128$

Table 3 Rates of acetylene reduction to ethylene by Beggiatoadominated biofilms and sulfidic sediment collected at the cave site Pozzo dei Cristalli (PC) within the Frasassi caves

\begin{tabular}{lcc}
\hline Sample & \multicolumn{2}{c}{ Ethylene $\left(\mathrm{nmolg}^{-1} \mathrm{~h}^{-1}\right)^{\mathrm{a}}$} \\
\cline { 2 - 3 } & February 2011 & May 2011 \\
& & \\
\hline Beggiatoa-dominated biofilm & PC-BeggB & PC-BeggC \\
Only biofilm & $3.94 \pm 0.24$ & $7.18 \pm 0.61$ \\
+ Molybdate & NM & $0.72 \pm 0.03$ \\
Sulfidic sediment & PC-SedA & PC-SedC \\
Only sediment & $3.27 \pm 0.11$ & $4.40 \pm 0.37$ \\
+ Molybdate & NM & $4.64 \pm 0.34$ \\
& &
\end{tabular}

Abbreviation: NM, not measured.

${ }^{a}$ Values over an interval of $1 \mathrm{~h}$ and $2 \mathrm{~h}$ were considered for biofilm and sediment, respectively.

${ }^{\mathrm{b}}$ Analyzed with two and three replicates for samples collected in

February and May, respectively.
(12 h), $0.176 \pm 0.032(24 \mathrm{~h}), 0.159 \pm 0.025(36 \mathrm{~h})$ and $0.151 \pm 0.026(48 \mathrm{~h})(n=2$ for all time points). The rate of fixation for the final time point $(120 \mathrm{~h})$ is not mentioned, because the isotope uptake did not increase for this time point (Figure 1).

\section{Diversity of nifH transcripts associated with distinct cave niches}

The results of RT-PCR for nifH genes ( $\sim 360 \mathrm{bp}$ ) were positive for all the investigated microbial niches associated with the cave waters (except $N$. ictus; see below), confirming the genetic potential for nitrogen fixation. nifH genes of the same size were also obtained from the DNA extracts of the microbial community associated with the legs of Niphargus spp. (Table 2). Cloning and phylogenetic analysis showed that all the nifH genes obtained in this study were novel (at least 2.5\% amino-acid sequence divergence with the sequences in GenBank, except for one sequence (Thio1d, Figure 2) that showed a divergence of $0.9 \% ; 120$ amino-acids were considered). The amino-acid alignments of translated nifH clones manifested the four cysteine and one arginine residues that are conserved in all nitrogenase iron proteins, corroborating the function of these genes in diazotrophy (Dean and Jacobson, 1992). The nifH clones showed distinct amino-acid signature patterns, which were used as a criterion to define a phylotype-the nifH clones possessing the same amino-acid signature pattern were treated as one phylotype. Based on the phylogenetic positions of the phylotypes, they all belonged to Proteobacteria and could be putatively assigned to distinct bacterial groups (Table 2; Figure 2).

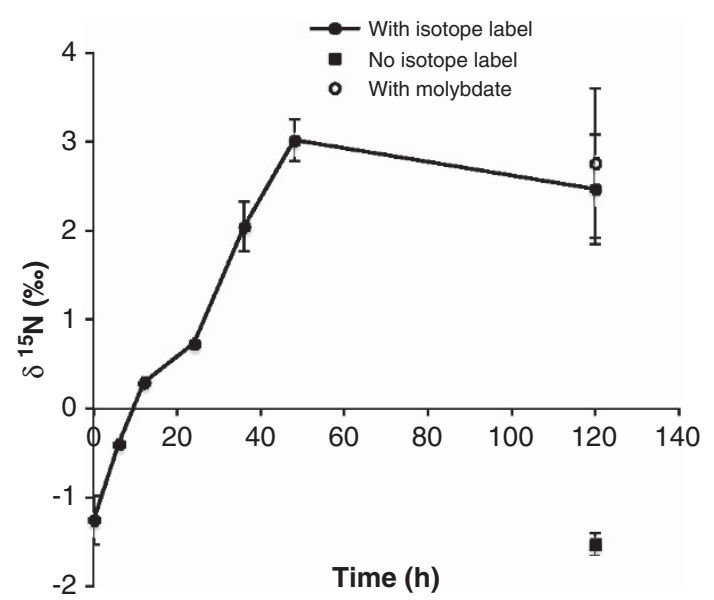

Figure 1 Bacterial uptake of ${ }^{15} \mathrm{~N}_{2}$ gas into the sulfidic sediment (PC-SedB; Table 1) collected at the cave site PC; error bars represent s.d. $(n=2)$. Uptake of the isotope label by sediment sample amended with molybdate (performed only for the final time point, $120 \mathrm{~h}$ ) is shown. The parallel experiment with the control without isotope label (also for the final time point, $120 \mathrm{~h}$ ) displays no significant change in the $\delta^{15} \mathrm{~N}$ value. 


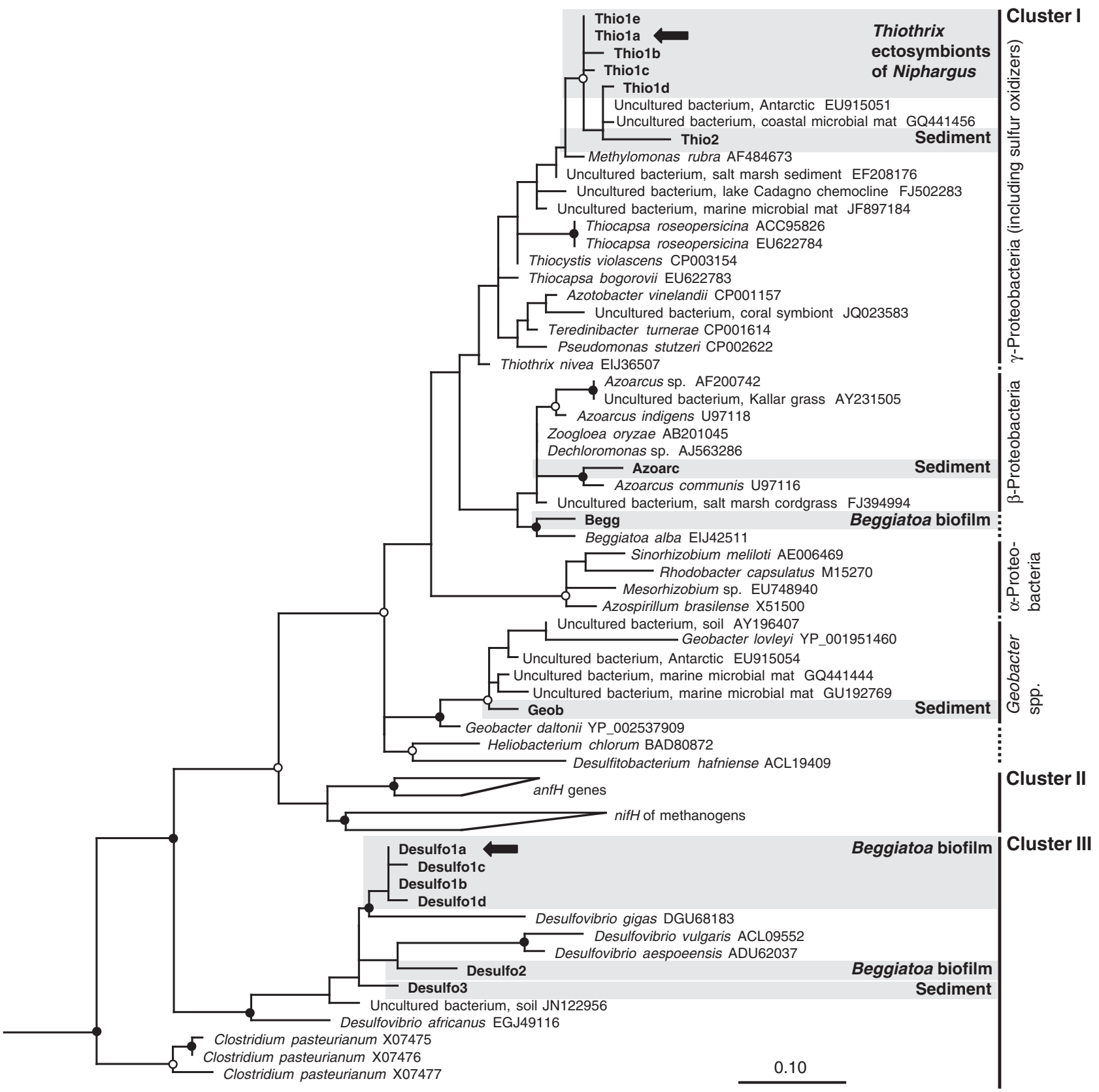

Figure 2 Maximum-likelihood tree exhibiting the phylogenetic relationship of nifH transcripts and genes derived from Niphargus spp., Beggiatoa-dominated biofilms and sulfidic sediment within the Frasassi caves with closely related and prototypical isolates and sequences obtained from other habitats. One hundred and three unambiguously aligned amino-acid positions were considered. Sequences from this study are shown in bold; when numerous closely related phylotypes were obtained from a particular sample, the preferentially expressed phylotype is shown with arrows (see Table 2 for details). Cluster nomenclature is based on Zehr et al. (2003b); vertical lines denote distinct nifH Clusters, and for Cluster I, different groups are connected with dotted lines. The tree was rooted using nifH gene of Methanosarcina barkeri (GenBank accession no. AB019139), which falls in Cluster IV. Tree topology was validated by maximum-parsimony analysis; nodes with strong bootstrap values are marked $(\bigcirc>50 \% ; \bullet>70 \%)$. For tentative assignment of different phylotypes to specific bacterial groups, see Discussion.

Out of the two Niphargus spp. (N. ictus and N. frasassianus; Table 1) that were analyzed with RT-PCR for the nifH transcripts of their symbiotic bacterial communities, only the samples of $N$. frasassianus showed transcripts of the expected size. The clone library prepared from the RT-PCR product consisted of two closely related phylotypes
(Thio1a and Thio1b; amino-acid identity $>98.3 \%$ ). However, only one phylotype (Thio1a) was preferentially expressed (Table 2; Figure 2). The phylotypes belonged to nifH Cluster I and fell into the $\gamma$-Proteobacteria nifH group comprising of nifH genes from various sulfur-oxidizing bacteria, with an amino-acid identity of $97.5 \%, 96.5 \%, 95.5 \%$ and 
92.5\% to Thiocystis violascens, Methylomonas rubra, Thiocapsa roseopersicina and Thiothrix nivea, respectively (percentage calculated with Thio1a). As Thiothrix ectosymbionts are abundant on the legs of these amphipods (Bauermeister et al., 2012), to locate the origin of expressed nifH phylotype on the amphipod body, we also carried out nifH clone libraries with the DNA extracted from the symbiotic microbial community associated with the legs of Niphargus spp. (Table 1). PCR products of the similar size were obtained from the legs' bacterial community of $N$. frasassianus; some individuals were collected at the same location during the same sampling trip, as of $N$. frasassianus used to examine nifH transcripts (Table 2). We also obtained nifH genes from the microbial community associated with the legs of a third species, N. montanarius (Table 2). Analyses of the nifH genes obtained from the microbial community of legs of all the Niphargus samples showed only phylotypes related to the $\gamma$-Proteobacteria group, except for one clone affiliated to the Geobacter group (phylotype: Geob; Table 2). The only expressed phylotype in the $N$. frasassianus transcript library, Thio1a, was always present in all the four leg-associated clone libraries (Table 2). The other phylotypes (Thio1b, c, d and e) had $>98.3 \%$ amino-acid sequence identity with Thio1a, strongly indicating that the bacteria carrying these nifH genes belong to the same genus.

We performed the nifH transcript analyses of the Beggiatoa biofilms collected during two sampling trips (July 2010 and May 2011) at the cave site PC (Table 1). It should be noted that when we collected the sediment samples in March 2011, the water levels in the stream had risen and no Beggiatoa biofilms were observed at PC. Thus, the biofilms were formed newly when the water levels decreased in May 2011. The nifH transcript analyses of both the biofilms displayed the existence of identical transcripts (Table 2; Figure 2). Although the aminoacid signature patterns of the phylotypes showed that both libraries comprised of several closely related Desulfovibrio-related phylotypes ( $>98.3 \%$ amino-acid sequence identity among several phylotypes), only one phylotype (Desulfo1a) was preferentially expressed in both the biofilms (Table 2). The second dominant phylotype (Begg), expressed in both the biofilms, belonged to the Cluster I and clustered together with the nifH gene of Beggiatoa alba, with an amino-acid identity of $93.5 \%$. The biofilm collected in July 2010 also contained the nifH phylotype (Geob) related to the Geobacter group that was found with the microbial community from the legs of $N$. frasassianus (Table 2).

nifH transcript analysis of the sulfidic sediment yielded four nifH phylotypes that were different from those found from Niphargus bacterial communities and the Beggiatoa biofilms, except for the phylotype Geob (see above). The phylotypes belonged to either Cluster I or Cluster III (Figure 2). The most abundant phylotype (Geob), obtained in low abundance in the Niphargus symbiotic bacterial community and the Beggiatoa biofilm, clustered together with the nifH genes of Geobacter spp. (96\% amino-acid identity with Geobacter lovleyi and Geobacter daltonii). The second dominant phylotype (Thio2) fell into the $\gamma$-Proteobacteria group and was closely related to the phylotypes derived from the symbiotic bacterial community of Niphargus spp. (Figure 2). The remaining two transcripts were present in equal proportion and clustered together with Desulfovibrio and Azoarcus spp. (Table 2, Figure 2; 95\% amino-acid identity to Azoarcus communis).

\section{Discussion}

Our report of nitrogen fixation from the sulfidedriven Frasassi caves (Italy) is the first demonstration of this ecologically important process from a permanently dark, chemoautotrophy-based cave ecosystem. The results of the acetylene reduction assay, ${ }^{15} \mathrm{~N}_{2}$ isotope studies and nitrogenase gene (nifH) expression analyses collectively document nitrogen fixation in various microbial niches in the cave waters. The nitrogen-fixing bacteria (diazotrophs) include ectosymbionts of Niphargus amphipods, occur within the chemoautotrophic Beggiatoa-dominated biofilms (Beggiatoa and Desulfovibrio related) and exist mostly as heterotrophs in the sulfidic sediment (Geobacter, Azoarcus and Desulfovibrio related). These findings display niche segregation of diazotrophic Proteobacteria within the cave water streams. As the Frasassi caves harbor an autochthonous ecosystem, diazotrophy may have an important role in sustaining both the microbial and macrofaunal diversity within the cave ecosystem (Sarbu et al., 2000). Our results suggest that nitrogen fixation may be prevalent in chemoautotrophy-based sulfidic caves in the other parts of the world (Sarbu et al., 1996; Chen et al., 2009; Gray and Engel, 2013) and may be widespread in both marine and terrestrial chemosynthetic ecosystems.

Three species of amphipods- $N$. ictus, $N$. frasassianus and $N$. montanarius-are prevalent in the streams and lakes of Frasassi caves (Flot et al., 2010; Karaman et al., 2010). All the three species carry host-specific filamentous ectosymbionts (on their legs and antennae) that belong to Thiothrix Clades T1, T2 and T3 in the 16S rRNA gene phylogeny (Dattagupta et al., 2009; Bauermeister et al., 2012). Based on the phylogenetic position of the nifH transcripts obtained from the microbial community associated with $N$. frasassianus and recovery of identical nifH genes from the ectosymbiotic bacterial community attached on the legs of several Niphargus specimens (Table 2), the expressed genes could be tentatively assigned to Thiothrix ectosymbionts (Figure 2). As N. frasassianus and N. montanarius share only Thiothrix Clade T3 ectosymbionts, a lineage that is distantly related to 
the other two lineages ( $\mathrm{T} 1$ and $\mathrm{T} 2$ ), the $\mathrm{T} 3$ ectosymbionts probably possess and express the nifH genes (Table 2; Figure 2). This is further corroborated by the fact that we did not obtain any nifH transcripts from the symbiotic community of $N$. ictus, which either completely lacks or sparsely possess the Clade T3 ectosymbionts (Bauermeister et al., 2012). It is possible that transintegumental transfer of nitrogenous compounds from the ectosymbionts to the Niphargus hosts occurs, similar to the transfer of fixed inorganic carbon that was recently shown for the ectosymbionts of the shrimp Rimicaris exoculata (Ponsard et al., 2013).

Another substantial source of nitrogen to Niphargus and other Frasassi-dwelling macroinvertebrates could be the chemoautotrophic biofilms growing in the cave waters. Among the numerous biofilm types, Beggiatoa biofilms offer an ideal niche for diazotrophic activity, as these gliding filamentous bacteria occur in a low oxygen niche (Preisler et al., 2007; Macalady et al., 2008). Although cultures of marine and freshwater Beggiatoa strains were shown to possess the ability to fix nitrogen (Nelson et al., 1982), nitrogenase activity and gene expression were not yet demonstrated in Beggiatoa biofilms, which are also abundant at deep-sea hydrothermal vents and reduced sediment habitats (Nelson et al., 1989; Preisler et al., 2007). The isotopically lighter $\delta^{15} \mathrm{~N}$ values of the Beggiatoa biofilm, nitrogenase activity (Table 3) and active expression of nifH genes (Table 2; Figure 2) undoubtedly demonstrate diazotrophic activity in these biofilms. The rates of ethylene production found in the acetylene reduction assay may be minimum estimates, as the biofilm was exposed to higher amounts of oxygen during collection and treatment as compared with its natural habitat, which could have reduced the efficacy of the oxygen-sensitive nitrogenase enzyme (Dixon and Kahn, 2004). The phylogenetic analysis of the nifH transcripts displays the identities of the diazotrophs as Desulfovibrio related and Beggiatoa spp. (Figure 2). Intriguingly, identical nifH genes were obtained in Beggiatoa biofilms collected at different time points, which may be owing to cell-to-cell signalling of these sulfur-cycling bacteria that can reform the biofilms when water levels in the caves are reduced.

Although syntrophic associations of sulfatereducing and sulfur-oxidizing (and carbon-fixing) bacteria are known (Dubilier et al., 2001), diazotrophy has not been found in such associations. Our study displays an example of nutritional availability and metabolic co-operativity in a biofilm, which are among the reasons why bacteria form biofilms (Davey and O'toole, 2000). As Desulfovibrio are strictly anaerobic and Beggiatoa bridges the gap between sulfidic and oxic microenvironments, our results suggest niche partitioning of the two distinct diazotrophs driven by steep redox conditions within the biofilm. Although the Desulfovibrio-related nifH transcripts are more abundant than those of Beggiatoa (Table 2), our small subunit rRNA transcript analysis of the biofilm PCBeggA demonstrated nearly $70 \%$ Beggiatoa and only $5 \% \delta$-Proteobacteria (details not shown; these sequences affiliated with Beggiatoa and $\delta$-Proteobacteria were identical to the 16S rRNA gene sequences with GenBank accession numbers DQ415807 and DQ133916, respectively; Macalady et al., 2008). An order of magnitude decrease in the rates of ethylene formation in the molybdate-supplemented biofilm (PC-BeggC; Table 3) further supports that the sulfate-reducing bacteria are the major diazotrophs in these biofilms. As the Beggiatoa biofilms failed to aggregate when molybdate was added, the sulfate-reducing bacteria may also be important in the formation of these biofilms. Alternatively, molybdate may have a direct inhibitory effect on the formation of these biofilms.

The diazotrophs in the underlying sediment, however, do not seem to contain the Beggiatoa biofilm-related nifH transcripts (Table 2; Figure 2). Our results of acetylene reduction assay, ${ }^{15} \mathrm{~N}_{2}$ isotope incorporation and nifH transcript analysis show consistent diazotrophic activity of mostly heterotrophic bacteria in the sulfidic sediment. The rates of ethylene formation in the acetylene reduction assay are in the same range as for bioturbated marine sediment (V. Bertics, personal communication) (Bertics et al., 2010), 4-6-fold higher than those of anoxic coastal sediments (Hartwig and Stanley, 1978), nearly 50-fold higher than the acidic high-temperature geothermal springs in Yellowstone National Park (YNP) (Hamilton et al., 2011) and about 25-fold greater than a lake sediment from Canada (Knowles, 1979). The $\delta^{15} \mathrm{~N}$ values of the Frasassi sediment are in the same range as reported for the sediment from the YNP, which also has diazotrophic activity (Hamilton et al., 2011; Loiacono et al., 2012). Incorporation of ${ }^{15} \mathrm{~N}_{2}$ gas by the cave sediment further corroborates autochthonous nitrogen fixation (Figure 1).

As the rates of nitrogen fixation obtained in the acetylene reduction assay and ${ }^{15} \mathrm{~N}_{2}$ isotope labelling did not change in the molybdate-amended sediment samples, it appears that the dominant diazotrophs in the sediment are not sulfate reducers. Instead, the most abundant nifH transcripts putatively belong to Geobacter, members of which are common heterotrophic diazotrophs in subsurface sediments (Holmes et al., 2004). It is striking to find Azoarcus-related nifH genes in the cave sediment-these bacteria are known to fix nitrogen only as symbionts within plant roots (Reinhold-Hurek and Hurek, 1997). As nitrogen fixation was observed in the sediment in different months (in the presence and absence of biofilms), it appears that the sediment is a consistent source of nitrogen for the cave ecosystem.

Considering that several locations within the Frasassi caves are seemingly connected with water 
channels (Galdenzi et al., 2008) and contain Beggiatoa biofilms and sediments, it is possible that the diazotrophs discovered in the cave site PC are spread in other locations within the cave system. Moreover, the Niphargus spp. possessing Thiothrix T3 ectosymbionts occur at numerous cave locations (Bauermeister et al., 2012). The low $\delta^{15} \mathrm{~N}$ values measured on the walls of Frasassi caves suggest ammonia degassing (Jones et al., 2008); thus, the fixed nitrogen may also be available for the microbial communities on the cave walls, for example, acidic snottites (Jones et al., 2012). Factors that might drive the level of diazotrophic activity and niche separation within Frasassi may include sulfide and oxygen concentrations in waters at distinct cave locations (Macalady et al., 2008), because high concentrations of both can completely shut down nitrogen fixation (Tam et al., 1982; Dixon and Kahn, 2004). Nitrate can also inhibit diazotrophy (Streeter, 1985), but the nitrate concentrations found in distinct water streams in Frasassi caves are negligible (Macalady et al., 2008). Nitrogen fixation within Frasassi occurs even in the presence of ammonium in the water streams. Despite the energetically expensive and highly regulated nature of the process of nitrogen fixation (Postgate, 1972), the presence of ammonium does not inhibit diazotrophy in other habitats also (Capone, 1988; McGlathery et al., 1998; Holl and Montoya, 2005; Bertics et al., 2010; Hamilton et al., 2011), the possible reasons for which have been discussed previously (Bertics et al., 2010).

\section{Conflict of Interest}

The authors declare no conflict of interest.

\section{Acknowledgements}

We thank German Excellence Initiative for funding. We are grateful to Simone Cerioni, Sandro Mariani and Jan Bauermeister for assistance with fieldwork; Alessandro Montanari for logistic support and laboratory facilities at the Osservatorio Geologico di Coldigioco; Saer Samanipour and Paolo Passamonti for help with the initial trials of the acetylene reduction assay; Andreas Brune and Katja Meuser for the GC-FID facility; Jens Dyckmans and Reinhard Langel for stable isotope analyses; Melanie Heinemann and Pia Sternisek for excellent technical assistance; Jean-François Flot and Jan Bauermeister for the DNA extracts (Niphargus spp. legs' microbial communities); and Daniel Jackson, Martin Blumenberg, Daniel S Jones and Rachel Foster for fruitful discussions. We also thank Victoria Bertics for sharing the porosity and density data of the sediment from her study, and Jennifer Macalady for help with the identification of Beggiatoa biofilm during a field trip. This article is contribution number 123 from the Courant Research Center Geobiology, University of Göttingen, Germany.

\section{References}

Bauermeister J, Ramette A, Dattagupta S. (2012). Repeatedly evolved host-specific ectosymbioses between sulfur-oxidizing bacteria and amphipods living in a cave ecosystem. PLoS One 7: e50254.

Bertics V, Sohm J, Treude T, Chow C, Capone DG, Fuhrman J et al. (2010). Burrowing deeper into benthic nitrogen cycling: the impact of bioturbation on nitrogen fixation coupled to sulfate reduction. Mar Ecol Prog Ser 409: 1-15.

Brooks JM, Kennicutt MC, Fisher CR, Macko SA, Cole K, Childress JJ et al. (1987). Deep-sea hydrocarbon seep communities: evidence for energy and nutritional carbon sources. Science 238: 1138-1142.

Capone DG. (1988). Benthic nitrogen fixation. In: Blackburn TH, Sørensen J (eds) Nitrogen Cycling in Coastal Marine Environments. Springer: New York, NY, USA, pp 105-137.

Capone DG, Montoya JP. (2001). Nitrogen fixation and denitrification. In: Paul J (ed) Methods in Microbiology vol. 30. Academic Press: London, UK, pp 501-515.

Chen Y, Wu L, Boden R, Hillebrand A, Kumaresan D, Moussard H et al. (2009). Life without light: microbial diversity and evidence of sulfur- and ammoniumbased chemolithotrophy in Movile Cave. ISME J 3: 1093-1104.

Chernousova E, Gridneva E, Grabovich M, Dubinina G, Akimov V, Rossetti S et al. (2009). Thiothrix caldifontis sp. nov. and Thiothrix lacustris sp. nov., gammaproteobacteria isolated from sulfide springs Int J Syst Evol Microbiol 59: 3128-3135.

Dang H, Luan X, Zhao J, Li J. (2009). Diverse and novel nifH and nifH-like gene sequences in the deep-sea methane seep sediments of the Okhotsk Sea. Appl Environ Microbiol 75: 2238-2245.

Dang H, Yang J, Li J, Luan X, Zhang Y, Gu G et al. (2013). Environment-dependent distribution of the sediment nifH-harboring microbiota in the Northern South China Sea. Appl Environ Microbiol 79: 121-132.

Dattagupta S, Schaperdoth I, Montanari A, Mariani S, Kita N, Valley JW et al. (2009). A novel symbiosis between chemoautotrophic bacteria and a freshwater cave amphipod. ISME J 3: 935-943.

Davey ME, O’toole GA. (2000). Microbial biofilms: from ecology to molecular genetics. Microbiol Mol Biol Rev 64: 847-867.

Dean DR, Jacobson MR. (1992). Biochemical genetics of nitrogenase. In: Stacy G, Burris RH, Evans HJ (eds). Biological Nitrogen Fixation. Chapman and Hall New York, pp 763-834.

Dekas AE, Poretsky RS, Orphan VJ. (2009). Deep-sea archaea fix and share nitrogen in methane-consuming microbial consortia. Science 326: 422-426.

Desai MS, Brune A. (2012). Bacteroidales ectosymbionts of gut flagellates shape the nitrogen-fixing community in dry-wood termites. ISME J 6: 1302-1313.

Dixon R, Kahn D. (2004). Genetic regulation of biological nitrogen fixation. Nat Rev Microbiol 2: 621-631.

Dubilier N, Mülders C, Ferdelman T, De Beer D, Pernthaler A, Klein M et al. (2001). Endosymbiotic sulphate-reducing and sulphide-oxidizing bacteria in an oligochaete worm. Nature 411: 298-302.

Dubilier N, Bergin C, Lott C. (2008). Symbiotic diversity in marine animals: the art of harnessing chemosynthesis. Nat Rev Microbiol 6: 725-740. 
Flot J-F, Wörheide G, Dattagupta S. (2010). Unsuspected diversity of Niphargus amphipods in the chemoautotrophic cave ecosystem of Frasassi, central Italy. BMC Evol Biol 10: 171.

Galdenzi SA, Cocchioni MA, Morichetti LU, Amici VA. (2008). Sulfidic ground-water chemistry in the Frasassi Caves, Italy. J Cave Karst Stud 70: 94-107.

Gray CJ, Engel AS. (2013). Microbial diversity and impact on carbonate geochemistry across a changing geochemical gradient in a karst aquifer. ISME J 7: 325-337.

Griffiths MSH, Gallon JR, Chaplin AE. (1987). The diurnal pattern of dinitrogen fixation by cyanobacteria in situ. New Phytol 107: 649-657.

Großkopf T, Mohr W, Baustian T, Schunck H, Gill D, Kuypers MMM et al. (2012). Doubling of marine dinitrogen-fixation rates based on direct measurements. Nature 488: 361-364.

Hamilton TL, Lange RK, Boyd ES, Peters JW. (2011). Biological nitrogen fixation in acidic high-temperature geothermal springs in Yellowstone National Park, Wyoming. Environ Microbiol 13: 2204-2215.

Hartwig EO, Stanley SO. (1978). Nitrogen fixation in Atlantic deep-sea and coastal sediments. Deep-Sea Res 25: 411-417.

Herbert RA. (1999). Nitrogen cycling in coastal marine ecosystems. FEMS Microbiol Rev 23: 563-590.

Holl CM, Montoya JP. (2005). Interactions between nitrate uptake and nitrogen fixation in continuous cultures of the marine diazotroph Trichodesmium (Cyanobacteria). J Phycol 41: 1178-1183.

Holmes DE, Nevin KP, Lovley DR. (2004). In situ expression of nifD in Geobacteraceae in subsurface sediments. Appl Environ Microbiol 70: 7251-7259.

Hongoh Y, Sharma VK, Prakash T, Noda S, Toh H, Taylor TD et al. (2008). Genome of an endosymbiont coupling N2 fixation to cellulolysis within protist cells in termite gut. Science 322: 1108-1109.

Jones DS, Albrecht HL, Dawson KS, Schaperdoth I, Freeman KH, Pi Y et al. (2012). Community genomic analysis of an extremely acidophilic sulfur-oxidizing biofilm. ISME J 6: 158-170.

Jones DS, Lyon EH, Macalady JL. (2008). Geomicrobiology of biovermiculations from the Frasassi Cave System, Italy. J Cave Karst Stud 70: 78-93.

Jørgensen BB. (1977). Distribution of colorless sulfur bacteria (Beggiatoa spp.) in a coastal marine sediment. Mar Biol 28: 19-28.

Karaman GS, Borowsky B, Dattagupta S. (2010). Two new species of the genus Niphargus Schiödte, 1849 (Amphipoda, fam. Niphargidae) from the Frasassi cave system in Central Italy. Zootaxa 2439: 35-52.

Kneip C, Lockhart P, Voss C, Maier UG. (2007). Nitrogen fixation in eukaryotes-new models for symbiosis. BMC Evol Biol 7: 55.

Knowles R. (1979). Denitrification, acetylene reduction, and methane metabolism in lake sediment exposed to acetylene. Appl Environ Microbiol 38: 486-493.

Loiacono ST, Meyer-Dombard DR, Havig JR, Poret-Peterson AT, Hartnett HE, Shock EL. (2012). Evidence for high-temperature in situ nifH transcription in an alkaline hot spring of Lower Geyser Basin, Yellowstone National Park. Environ Microbiol 14: 1272-1283.

Macalady JL, Dattagupta S, Schaperdoth I, Jones DS, Druschel GK, Eastman D. (2008). Niche differentiation among sulfur-oxidizing bacterial populations in cave waters. ISME J 2: 590-601.

Macalady JL, Lyon EH, Koffman B, Albertson LK, Meyer K, Galdenzi SA et al. (2006). Dominant microbial populations in limestone-corroding stream biofilms, Frasassi cave system, Italy. Appl Environ Microbiol 72: 5596-5609.

McGlathery KJ, Risgaard-Petersen N, Christensen PB. (1998). Temporal and spatial variation in nitrogen fixation activity in the eelgrass Zostera marina rhizosphere. Mar Ecol Prog Ser 168: 245-258.

Mehta MP, Baross JA. (2006). Nitrogen fixation at 92 degrees $\mathrm{C}$ by a hydrothermal vent archaeon. Science 314: 1783-1786.

Mehta MP, Butterfield DA, Baross JA. (2003). Phylogenetic diversity of nitrogenase (nifH) genes in deep-sea and hydrothermal vent environments of the Juan de Fuca Ridge. Appl Environ Microbiol 69: 960-970.

Miyazaki J, Higa R, Toki T, Ashi J, Tsunogai U, Nunoura T et al. (2009). Molecular characterization of potential nitrogen fixation by anaerobic methane-oxidizing archaea in the methane seep sediments at the number 8 Kumano Knoll in the Kumano Basin, offshore of Japan. Appl Environ Microbiol 75: 7153-7162.

Mohr W, Grosskopf T, Wallace DWR, LaRoche J. (2010). Methodological underestimation of oceanic nitrogen fixation rates. PLoS One 5: e12583.

Montoya JP, Voss M, Kahler P, Capone DG. (1996). A simple, high-precision, high-sensitivity tracer assay for $\mathrm{N}_{2}$ fixation. Appl Environ Microbiol 62: 986-993.

Nelson DC, Revsbech P, Jørgensen BB. (1986). Microoxic-anoxic niche of Beggiatoa spp.: microelectrode survey of marine and freshwater strains. Appl Environ Microbiol 52: 161-168.

Nelson DC, Waterbury John B, Jannasch Holger W. (1982). Nitrogen fixation and nitrate utilization by marine and freshwater Beggiatoa. Arch Microbiol 133: 172-177.

Nelson DC, Wirsen CO, Jannasch HW. (1989). Characterization of large, autotrophic Beggiatoa spp. abundant at hydrothermal vents of the Guaymas basin Appl Environ Microbiol 55: 2909-2917.

Ohkuma M, Noda S, Kudo T. (1999). Phylogenetic diversity of nitrogen fixation genes in the symbiotic microbial community in the gut of diverse termites. Appl Environ Microbiol 65: 4926-4934.

Oremland RS, Capone DG. (1988). Use of specific inhibitors in biogeochemistry and microbial ecology. Adv Microb Ecol 10: 285-383.

Petersen JM, Zielinski FU, Pape T, Seifert R, Moraru C, Amann R et al. (2011). Hydrogen is an energy source for hydrothermal vent symbioses. Nature 476: 176-180.

Ponsard J, Cambon-Bonavita M-A, Zbinden M, Lepoint G, Joassin A, Corbari L et al. (2013). Inorganic carbon fixation by chemosynthetic ectosymbionts and nutritional transfers to the hydrothermal vent host-shrimp Rimicaris exoculata. ISME J 7: 96-109.

Postgate JR. (1972). Biological nitrogen fixation. Nature 226: 25-27.

Preisler A, De Beer D, Lichtschlag A, Lavik G, Boetius A, Jørgensen BB. (2007). Biological and chemical sulfide oxidation in a Beggiatoa inhabited marine sediment. ISME J 1: 341-353.

Rau GH. (1981). Low $15 \mathrm{~N} / 14 \mathrm{~N}$ in hydrothermal vent animals: ecological implications. Nature 289: 484-485. 
Reinhold-Hurek B, Hurek T. (1997). Azoarcus spp. and their interactions with grass roots. Plant Soil 20: $526-533$.

Sarbu S, Kane T, Kinkle B. (1996). A chemoautotrophically based cave ecosystem. Science 272: 1953-1955.

Sarbu S, Galdenzi S, Menichetti M, Gentile G. (2000). Geology and biology of the Frasassi caves in central Italy: an ecological multi-disciplinary study of a hypogenic underground karst system. In: Wilkens $\mathrm{H}$ (ed) Ecosystems of the World. Elsevier: New York, NY, USA, pp 359-378.

Stewart FJ, Newton ILG, Cavanaugh CM. (2005). Chemosynthetic endosymbioses: adaptations to oxicanoxic interfaces. Trends Microbiol 13: 439-448.

Stewart WD, Fitzgerald GP, Burris RH. (1967). In situ studies on $\mathrm{N}_{2}$ fixation using the acetylene reduction technique. Proc Natl Acad Sci USA 58: 2071-2078.

Streeter JG. (1985). Nitrate inhibition of legume nodule growth and activity: I. Long term studies with a continuous supply of nitrate. Plant Physiol 77: 321-324.

Tam TY, Mayfield CI, Inniss WE, Knowles R. (1982). Effect of sulfide on nitrogen fixation in a stream sedimentwater system. Appl Environ Microbiol 43: 1076-1079.
Werner R, Bruch B, Brand W. (1999). ConFlo III-an interface for high precision delta(13)C and delta(15)N analysis with an extended dynamic range. Rapid Commun Mass Spectrom 13: 1237-1241.

Zehr JP, Crumbliss LL, Church MJ, Omoregie EO, Jenkins BD. (2003a). Nitrogenase genes in PCR and RT-PCR reagents: implications for studies of diversity of functional genes. BioTechniques 35: 996-1002. 1004-1005.

Zehr JP, Jenkins BD, Short SM, Steward GF. (2003b). Nitrogenase gene diversity and microbial community structure: a cross-system comparison. Environ Microbiol 5: 539-554.

Zehr JP, Waterbury JB, Turner PJ, Montoya JP, Omoregie E, Steward GF et al. (2001). Unicellular cyanobacteria fix $\mathrm{N}_{2}$ in the subtropical North Pacific Ocean. Nature 412: 635-638.

(c) (1) $\odot$ This work is licensed under a Creative (a) Commons Attribution-NonCommercialNoDerivs 3.0 Unported License. To view a copy of this license, visit http://creativecommons.org/ licenses/by-nc-nd/3.0/ 